\title{
МЕТОДОЛОГІЧНІ АСПЕКТИ ПІДГОТОВКИ МАЙБУТНІХ УЧИТЕЛІВ МУЗИЧНОГО МИСТЕЦТВА ДО ВИХОВАННЯ ШКОЛЯРІВ ЗАСОБАМИ ДЗВОНАРСТВА
}

\author{
Ільчук Л. П. \\ кандидат педагогічних наук, \\ старший викладач кафедри мистеиьких дисичилін та методик їх навчання \\ Кременецька обласна гуманітарно-педагогічна академія імені Тараса Шевченка \\ вул. Лічейна, 1, Кременець, Тернопільська область, Украӥна \\ orcid.org/0000-0003-4871-0979 \\ linapetrivna@ukr.net
}

\author{
Ключові слова: професійна \\ підготовка, науково- \\ методологічні підходи, \\ студенти, дзвонарське \\ мистеитвво.
}

\begin{abstract}
У статті охарактеризовано теоретико-методологічні аспекти професійної підготовки майбутніх учителів музичного мистецтва до виховання школярів засобами дзвонарства. Визначено необхідність формування означеної готовності майбутніх педагогів-музикантів із позицій особистісно орієнтованого, культурологічного, етнопедагогічного, діяльнісного, компетентнісного, синергетичного й аксіологічного підходів. З'ясовано, що особистісно орієнтований підхід сприяє розвитку індивідуально-пізнавальних можливостей i здібностей майбутніх учителів, допомагає глибше пізнати себе, самоактуалізуватися та самореалізуватися у професії. Основою діяльнісного підходу $\epsilon$ соціально-виховний аспект майбутньої професійної діяльності студентів, спрямованої на пізнання дзвонарства, дослідження його національних ознак, розмаїття проявів. Культурологічний підхід орієнтує процес фахової підготовки майбутніх педагогів-музикантів на певний змістовий контент, збагачений відомостями про дзвонарську культуру, що сприяє формуванню загальнолюдських і національно-культурних цінностей особистості. Етнопедагогічний підхід орієнтує освітній процес у вищій школі на національні традиції та ментальні особливості української нації, іiі культури, національно-етнічної обрядовості і звичаїв, що стосуються дзвонарства як важливої ознаки самобутності народу. У руслі компетентнісного підходу визначено формування висококомпетентного професіонала, який володіє загальними і спеціальними знаннями, вміннями і навичками використання виховного потенціалу дзвонарства в роботі зі школярами. Синергетичний підхід передбачає відкритість, нелінійність освіти майбутніх педагогів, визнання їхніх індивідуальних потреб і можливостей. Використання аксіологічного підходу формує у студентів ціннісні орієнтації, шанобливе ставлення до дзвонарського мистецтва, визначає зміст виховання учнів на засадах педагогічних цінностей і морально-духовного, естетично-пізнавального потенціалу засобів дзвонарства. Встановлено, що комплексне використання означених наукових підходів сприятиме вирішенню суперечностей, що супроводжують процес професійної підготовки майбутніх педагогівмузикантів до виховання школярів засобами дзвонарства.
\end{abstract}




\title{
METHODOLOGICAL ASPECTS OF PREPARATION OF FUTURE TEACHERS OF MUSIC ART FOR EDUCATION OF SCHOOLCHILDREN BY MEANS OF BELL RINGING
}

\author{
Ilchuk L. P. \\ Candidate of Pedagogical Sciences, \\ Senior Lecturer at the Department of Art Disciplines and Methods of their Teaching \\ Taras Shevchenko Regional Humanitarian-Pedagogical Academy of Kremenets \\ Litseina str., 1, Kremenets, Ternopil region, Ukraine \\ orcid.org/0000-0003-4871-0979 \\ linapetrivna@ukr.net
}

Key words: professional training, scientific and methodological approaches, students, bell ringing art.

\begin{abstract}
The article describes the theoretical and methodological aspects of professional training of future teachers of music to education of schoolchildren by means of bell-ringing. The necessity of formation of the specified readiness of future teachers-musicians from positions of the person-oriented, culturological, ethnopedagogical activity, competence, synergetic and axiological approaches is defined. It was found that the personality-oriented approach promotes the development of individual cognitive abilities and abilities of future teachers, helps to know themselves better, self-actualization and self-realization in the profession. The basis of the activity approach is the social and educational aspect of the future professional activity of students aimed at learning bell ringing, the study of its national characteristics, a variety of manifestations. The culturological approach orients the process of professional training of future music teachers to a certain semantic content, enriched with information about the bell-ringing culture, which contributes to the formation of universal and national-cultural values of the individual. The ethnopedagogical approach orients the educational process in higher education to the national traditions and mental features of the Ukrainian nation, its culture, national and ethnic rites and customs related to bellringing as an important sign of the people's identity. In line with the competence approach, the formation of a highly competent professional who has general and special knowledge, skills and abilities to use the educational potential of bellringing in working with students is determined. The synergetic approach involves openness, nonlinearity of education of future teachers, recognition of their individual needs and opportunities. The use of the axiological approach forms in students value orientations, respect for the art of bell-ringing, determines the content of education of students on the basis of pedagogical values and moralspiritual, aesthetic-cognitive potential of bell-ringing. It is established that the integrated use of these scientific approaches will help resolve the contradictions that accompany the process of professional training of future music teachers to education of schoolchildren by means of bell-ringing.
\end{abstract}

Постановка проблеми. Сучасні трансформації в мистецькій освіті детермінують необхідність постійного вдосконалення підготовки майбутніх учителів музичного мистецтва. 3-поміж низки нерозв'язаних проблем - суспільне замовлення на формування компетентного педагога, готового до здійснення освітнього процесу на засадах традиційно-інноваційних, полімистецьких підходів. Пошук шляхів вирішення цих питань передбачає обгрунтування науково-методологічних основ оптимізації професійної готовності майбутніх освітян до використання у вихованні школярів різних засобів, зокрема дзвонарства.
Аналіз останніх досліджень і публікацій. Професійне становлення майбутніх учителів музичного мистецтва у контексті загальнонаукової і конкретнонаукової методології розглядала низка науковців: особистісно орієнтований підхід (В. Андрущенко, I. Бех, Н. Волкова, І.Зязюн); діяльнісний підхід (I. Княжева, А. Леонтьева, С. Сисоєва, Т. Тихонова); системний підхід (О. Дубасенюк, Т. Кочубей, Н. Салига, Н. Фоміцька); культурологічний підхід (В. Дряпіка, Г. Падалка, О. Рудницька, О. Савченко, В. Тушева); етнопедагогічний підхід (О. Олексюк, М. Пантюк, 
Т. Пантюк, Л. Соляр); синергетичний підхід (В. Лутай, Л. Ткаченко, О. Чалий); компетентнісний підхід (О. Глузман, Л. Гуцан, О. Дубасенюк, О. Часнікова); аксіологічний підхід (С. Вітвицька, С. Гаврилюк, М. Ткач, А. Щербакова); герменевтичний підхід (А. Закірова, А. Линенко, Ф. Шлеєрмахер); креативний підхід (О. Антонова, В. Мадзігон, А. Нісімчук С. Терещенко).

За підсумками аналізу наукових напрацювань установлено, що методологічні основи формування готовності педагогів-музикантів до виховання школярів засобами дзвонарства ще не розглянуто. Мета статті полягає у визначенні й характеристиці науково-методологічних підходів, у контексті яких вирішуються різні аспекти фахової підготовки майбутніх учителів музичного мистецтва до досліджуваної діяльності.

Виклад основного матеріалу. Наукова методологія - це система принципів і прийомів моделювання теоретико-практичної діяльності особистості. Методологічним підгрунтям проблеми вибрали ті наукові підходи, які, на нашу думку, враховують специфіку підготовки майбутніх учителів музичного мистецтва до виховання школярів засобами дзвонарства та сприяють розв'язанню теоретичних і прикладних завдань розвідки. До таких підходів відносимо особистісно орієнтований, культурологічний, діяльнісний, компетентнісний, синергетичний, аксіологічний та етнопедагогічний. Варто розглянути згадані підходи деталізовано.

Використання особистісно орієнтованого підходу в освітньому процесі створює передумови для розвитку та проявлення певних якостей індивідуума. В особистості формується творче мислення, інтелект, креативні i комунікативні здібності, виробляються навички до самоосвіти та саморозвитку. На думку І. Беха, особистісно орієнтований виховний процес передбачає повноцінне емоційно насичене й суспільно значуще, сумісне, творче життя педагога і вихованців відповідно до їхніх основних соціогенних потреб $[2$, c. 56]. Водночас А. Коробченко переконаний, що такий підхід визнає здобувача центральною діючою особою освітнього процесу, створює такі умови, за яких майбутній учитель виступає не виконавцем чи спостерігачем, а повноправним автором своєї «життєвої позиції», відповідальним за власні вчинки $[6$, с. 7].

Вибраний підхід потенційно розкриває індивідуально-пізнавальні можливості та здібності майбутніх освітян, допомагає глибше пізнати себе, самоактуалізуватися та самореалізуватися. Тому процес професійної підготовки має бути спрямований на особистість майбутнього вчителя музичного мистецтва, орієнтувати його на мету, кінцевий результат і важливі критерії готовності до виховання школярів засобами дзвонарства.
Описаний вище підхід доповнює культурологічний, який сфокусований на системі ціннісних уявлень і переконань особистості та є підвалиною iї особистісних орієнтирів, налагоджуючи та впорядковуючи діяльність. Педагогіка вищої школи визначає культурологічний підхід методологічним базисом особистісно орієнтованого навчання, збагаченого культурним i духовним змістом i спрямованого на успішне формування вселюдських цінностей у майбутніх учителів музичного мистецтва.

Науковці вважають культурологічний підхід сукупністю теоретико-методологічних положень та організаційно-педагогічних заходів, які спрямовані на забезпечення умов для оволодіння майбутніми педагогами педагогічною культурою та ціннісними орієнтирами [1, с. 105]. Так, вивчаючи проблему фахової підготовки майбутнього вчителя з позиції культурології, О. Савченко здійснює iii аналіз на ціннісному (аксіологічному), системно-цілісному та особистісно-діяльнісному рівнях. На підставі цього науковиця робить висновок про те, що зазначений підхід зумовлює формування педагогічних цінностей учителів, розвиває творчі якості, розкриває можливості самореалізації у професійній діяльності [9, с. 146].

Враховуючи культурологічний підхід, процес фахової підготовки майбутніх педагогів-музикантів орієнтується на певний змістовий контент, збагачений відомостями про дзвонарську культуру, який сприяє формуванню відповідних дзвонознавчих компетентностей студентів. Водночас цей підхід інтеріоризує в особистість загальнолюдські та національно-культурні цінності, розвиває прагнення студентської молоді до систематичного особистісно-професійного росту та самовдосконалення, забезпечує формування висококультурного фахівця.

Зважаючи на проблематику започаткованої наукової розвідки, важливим розглядаємо етнопедагогічний підхід. Він детермінує навчання i виховання на основі національних традицій і ментальних особливостей нашої нації, іiї культури, національно-етнічної обрядовості та звичаїв. Адже саме дзвонарство, яке пронизує різні сфери життя народу, стало важливою ознакою його самобутності [5, с. 39]. Ми цілком згідні з О. Олексюк, що «виховання з опиранням на національні традиції народу, його культуру, обрядовість, звичаї, звички $є$ умовою реалізації етнопедагогічного підходу до педагогічного процесу» $[8$, с. 26].

Нині відбувається активне відродження дзвонарської культури України, яка $€$ її етнонаціональною цінністю, вивчається педагогічний потенціал засобів дзвонарства, водночас виховання школярів грунтується на народності. Саме тому застосування етнопедагогічного підходу в підготовці 
майбутніх учителів музичного мистецтва рекомендуємо здійснювати у кількох напрямах, таких як: 1) поглиблене вивчення дзвонарської культури свого народу, що уможливить повноцінний розвиток світогляду вихованців і сформує професійні погляди і цінності студентів; 2) залучення майбутніх фахівців до науково-дослідницької та пошукової діяльності в галузі кампанології 3 метою пошуку, запису й аналізу різної інформації про дзвони, розуміння семантичного значення дзвонінь тощо; 3) занурення здобувачів у стихію народних традицій, звичаїв та обрядів, пов'язаних iз дзвонарством [5, с. 39].

Методологічне поле формування готовності майбутніх учителів до використання засобів дзвонарства у професійній діяльності влучно доповнює діяльнісний підхід. Т. Тихонова вважає його таким, що «забезпечує розвиток студентів на основі виявлення їхніх індивідуальних особливостей, а також спрямовує на особистісно орієнтовану професійно-педагогічну діяльність» [10, с. 102-105]. Ми переконані в тому, що цей підхід убезпечуватиме соціально-виховний аспект майбутньої фахової діяльності студентів, спрямованої не тільки на пізнання дзвонарства, а й на дослідження його національних ознак, розмаїття проявів.

Діяльнісний підхід реалізується за схемою «потреба - мотив - дія» й уможливлює розуміння сутності формування дзвонознавчих компетентностей майбутніх педагогів-музикантів. Але насамперед сприяє визначенню закономірностей цього процесу, забезпечує взаємозв'язок між засвоєнням теоретичних знань та їх практичним утіленням.

Освітній процес за своєю сутністю є складною, динамічною системою, такою, що постійно змінюється та набуває нових характеристик, якостей, саме тому синергетичний підхід виступає одним із пріоритетних у соціально-педагогічних дослідженнях. У підготовці майбутніх освітян він передбачає відкритість, нелінійність їх освіти, визнання індивідуальних потреб і можливостей студента. Вважаємо, що означений підхід доцільно застосовувати у процесі розв'язання суперечностей, що супроводжують підготовку майбутніх учителів музичного мистецтва. Адже тоді відбувається трансформація ціннісних орієнтацій на самопізнавальну й самовиховну активність особистості, а навчання здобувача виступає як самоорганізована та комплексна система.

Важливим i логічним у контексті нашого дослідження розглядаємо компетентнісний підхід, який відображає формування програмних компетентностей та результатів навчання майбутніх педагогів. Використання цього підходу зумовлене реформуванням системи освіти та суспільною потребою у компетентних фахівцях, готових до інноваційної професійної діяльності, самоосвіти, здатних пристосовуватися до нових вимог ринку праці. Вивчаючи проблему компетентнісного підходу, О. Глузман вважає, що компетентність не лише поєднує знаннєву й операційно-технологічну складові частини, а й включає мотиваційний, етичний, соціально-поведінковий компоненти, систему ціннісних орієнтацій, інші результати навчання. Тому формування компетентностей відбувається не лише у процесі навчання, але й у родинному середовищі, в колі друзів, соціальної діяльності, політики, релігії тощо [3, c. 51-61].

У компетентнісному підході відображено соціальний запит на підготовку майбутніх учителів музичного мистецтва до виховання школярів різними засобами, у тому числі дзвонарством. Вагоме значення такий підхід має для створення особливих педагогічних умов самоорганізації освітньої діяльності студентської молоді, виявлення та розвитку в них креативно-творчого потенціалу. Передумовою формування компетентності майбутніх педагогів-музикантів у сфері використання педагогічного потенціалу дзвонарства розглядали оволодіння ними загальними фаховими й особистісними компетентностями. Метою підготовки майбутніх педагогів-музикантів до досліджуваної діяльності у річищі компетентнісного підходу розглядали створення такого фахівця, який володіє різноманітними загальними і спеціальними знаннями, вміннями і навичками та спроможний успішно здійснювати професійну діяльність [5, с. 44].

Для теми нашої розвідки значний інтерес становить аксіологічний підхід, оскільки він визначає систему цінностей професійного та особистісного становлення майбутніх учителів. Аксіологічний підхід оперує низкою таких дефініцій аксіології, як: «цінності», «ціннісні орієнтації», «ціннісне ставлення», «цінності культури». На думку Н. Овчаренко, цінностями культури є витвори людського розуму, духу й творчої діяльності, зафіксовані в реальних здобутках і продуктах науки, мистецтва, моралі тощо $[7$, с. 40$]$. Тож першочерговим завданням вважаємо формування у студентської молоді стійкого інтересу та поваги до дзвонарської культури, ціннісного ставлення до людей, які створювали окремі цінності в означеній сфері, а також усвідомлення значення складників дзвонарства для всебічного розвитку особистості $[5$, c. 46$]$. Водночас аксіологічний підхід сприяє аналізу процесу формування системи знань, умінь, навичок у майбутніх педагогів-музикантів шляхом набуття ціннісних орієнтацій, шанобливого ставлення до дзвонарської культури, 
змісту й результатів використання ii засобів у роботі зі школярами на засадах педагогічних цінностей і морально-духовного, естетично-пізнавального значення дзвонарства.

Висновки та перспективи дослідження. Отже, підсумовуючи, відзначимо, що науковці трактують зміст професійної підготовки майбутніх фахівців музичного мистецтва 3 позицій різних науково-методологічних підходів, а напрацювання у цій галузі психологів і педагогів сприяли грунтовному визначенню загальнонаукової методології. Основними теоретико-методологічними підходами, які доцільно використовувати під час оптимізації процесу навчання майбутніх учителів, $є$ : особистісно орієнтований, культурологічний, діяльнісний, компетентнісний, синергетичний, аксіологічний та етнопедагогічний. Розглянуті в комплексі означені підходи сприятимуть розв'язанню суперечностей, що супроводжують процес професійної підготовки майбутніх педагогів-музикантів до виховання школярів засобами дзвонарства. Перспективами подальшого вивчення порушеної проблеми $є$ пошук ефективних інноваційних методик і технологій застосування виховного потенціалу дзвонарства в роботі зі школярами.

\section{ЛІТЕРАТУРА}

1. Аніщенко В., Падалка О. Культурологічний підхід у професійній підготовці вчителя. Освіта дорослих: теорія, досвід, перспективи: зб. наук. праць Ін-ту пед. освіти і освіти дорослих НАПН України. Ніжин : Видавець П.П. Лисенко М.М., 2013. Вип. 6. 289 с.

2. Бех І.Д. Виховання особистості: у 2 кн. Кн. 1: Особистісно орієнтований підхід: теоретико-технологічні засади. Київ : Либідь, 2003. 280 с.

3. Глузман О.В. Базові компетентності: сутність та значення в життєвому успіху особистості. Педагогіка і психологія. Київ, 2009. № 2. С. 51-61.

4. Дубасенюк О.А. Розвиток системних досліджень у науковому знанні: історія, досвід, перспективи. Професійна педагогічна освіта: системні дослідження: монографія. Житомир : Вид-во ЖДУ ім. І. Франка, 2015. С. 12-28.

5. Ільчук Л.П. Підготовка майбутніх учителів музичного мистецтва до виховання підлітків засобами дзвонарства: дис. ... канд. пед. наук: 13.00.04 / ДВНЗ «Прикарпатський національний університет ім. Василя Стефаника». Івано-Франківськ, 2018. 288 с.

6. Коробченко А.А. Проблеми особистісно орієнтованого навчання у вищих навчальних закладах. 3б. наук. праць Бердянського державного педагогічного університету. Серія: Педагогічні науки. Бердянськ : БДПУ, 2005. № 4.210 с.

7. Овчаренко Н.А. Теоретико-методологічні засади професійної підготовки майбутніх учителів музичного мистецтва до вокально-педагогічної діяльності: дис. ... д-ра пед. наук: 13.00.04 / ДВНЗ «Криворізький національний університет». Кривий Ріг, 2016. 547 с.

8. Олексюк О.М. Музична педагогіка : навч. посіб. Київ : КНУКіМ, 2006. 188 с.

9. Савченко О.П. Культурологічний підхід до підготовки майбутніх учителів. Наук $і$ освіта. Одеса, 2012. № 8. C. 146-148.

10. Тихонова Т.В. Особистісно-діяльнісний підхід у професійній підготовці майбутнього вчителя інформатики. Наукові праиі Чорном. держ. ун-ту ім. П. Могили. Миколаїв, 2000. Т. 7. С. 102-105.

\section{REFERENCES}

1. Anishchenko V., Padalka O. (2013) Kulturolohichnyi pidkhid u profesiinii pidhotovtsi vchytelia. [Culturological approach in teacher training]. Adult education: theory, experience, prospects: coll. Science. prats In-tu ped. education and adult education NAPS of Ukraine. Nizhyn: Publisher PP Lysenko M.M,. Vol. 6. 289 p.

2. Bekh I.D. (2003) Vykhovannia osobystosti: u 2 kn. Kn. 1: Osobystisno oriientovanyi pidkhid: teoretykotekhnolohichni zasady. [Education of personality: in 2 books. Book 1: Personality-oriented approach: theoretical and technological principles]. Kyiv: Lybid. 280 p.

3. Gluzman O.V. (2009) Bazovi kompetentnosti: sutnist ta znachennia v zhyttievomu uspikhu osobystosti. [Basic competencies: essence and significance in the life success of the individual]. Pedagogy and psychology. Kyiv. № 2. P. 51-61.

4. Dubaseniuk O.A. (2015) Rozvytok systemnykh doslidzhen u naukovomu znanni: istoriia, dosvid, perspektyvy. [Development of systems research in scientific knowledge: history, experience, prospects]. Professional pedagogical education: system research: monograph. Zhytomyr : ZhSU Publishing House. I. Franko. P. 12-28.

5. Ilchuk L.P. (2018) Pidhotovka maibutnikh uchyteliv muzychnoho mystectva do vykhovannia pidlitkiv zasobamy dzvonarstva. [Preparation of future teachers of music art for education of teenagers by means 
of bell ringing]: dissertation of the candidate of pedagogical sciences: SHEI "Precarpathian National University named after Vasyl Stefanyk". Ivano-Frankivsk. 288 p.

6. Korobchenko A.A. (2005) Problemy osobystisno oriientovanoho navchannia u vyshchykh navchalnykh zakladakh. [Problems of personality-oriented learning in higher education]. Coll. Science. Proceedings of Berdyansk State Pedagogical University. Series : Pedagogical sciences. Berdiansk : BSPU. Vol. 4. 210 p.

7. Ovcharenko N.A. (2016) Teoretyko-metodolohichni zasady profesiinoi pidhotovky maibutnikh uchyteliv muzychnoho mystetstva do vokalno-pedahohichnoi diialnosti. [Theoretical and methodological principles of professional training of future teachers of music to vocal and pedagogical activities]: dissertation of the doctor of pedagogical sciences. SHEI "Kryvyi Rih National University". Kryvyi Rih. 547 p.

8. Oleksyuk O.M. (2006) Muzychna pedahohika. [Music pedagogy]: textbook. Kyiv: KNUKiM. 188 p.

9. Savchenko O.P. (2012) Kulturolohichnyi pidkhid do pidhotovky maibutnikh uchyteliv. [Culturological approach to the training of future teachers]. Science and education. Odesa. Vol. 8. P. 146-148.

10. Tikhonova T.V. (2000) Osobystisno-diialnisnyi pidkhid u profesiinii pidhotovtsi maibutnoho vchytelia informatyky. [Personal-activity approach in the training of future teachers of computer science]. Scientific works by Black. state un-tu them. P. Graves. Mykolaiv. T. 7. P. 102-105. 